九州大学学術情報リポジトリ

Kyushu University Institutional Repository

Studies On The Sex-Linked Inheritance of Plumage Color In The Ring Dove, Streptopelia Risoria.

Tange, Masaharu

Laboratory of Zootechny, Department of Agriculture, Kyushu Imperial University

https://doi.org/10.5109/22571

出版情報：九州大学大学院農学研究院紀要. 4 (4)，pp.161-194，1934-12. Kyushu Imperial University バージョン：

権利関係 : 


\title{
STUDIES ON THE SEX-LINKED INHERITANCE OF PLUMAGE COLOR IN THE RING DOVE, STREPTOPELIA RISORIA. ${ }^{1}$
}

\author{
Masaharu TANGE
}

\begin{abstract}
CONTENTS
INTRODLCTION . . . . . . . . . . . . . . . . . . . . . . . . . 161

MATERIAL AND METHODS . . . . . . . . . . . . . . . . . . . . 163

EXPERIMENTAL RESULTS . . . . . . . . . : . . . . . . . . . 165

(I) Results of the crossing of blond ring doves with white ones . . . . 165

(II) Results of the crossing of white or albino ring doves with blond ones related to the occurrence of albino individuals, and further data on the albino ring dove . . . . . . . . . . . . . . . . . . . 173

(III) Results of the crossing of albino ring doves with white ones. . . . 175 DISCUSSION . . . . . . . . . . . . . . . . . . 176 SUMMARY . . . . . . . . . . . . . . . . . . . . . . . . . 192 BIBLIOGRAPHY . . . . . . . . . . . . . . . . . . . . . . . 193 EXPLANATION OF PLATE I. . . . . . . . . . . . . . . . . . . 194
\end{abstract}

\section{INTRODUCTION}

In domestic pigeons, Columba livia, various colors of plumage, such as black (COLE, 1914; STEEJE, 1931; HAwKIns, 1931), chocolate (Christie and Wriedt, 1927; Steele, 1931; Hawkins, 1931), and dominant red (Cole, 1914; Cole and Kediey, 1919; Steele, 1931; Hawkins, 1931), as well as a genetic factor for intensity of color (Cole, 1912; STEele, 1931; Hawkins, 1931) have been reported to be sex-linked in inheritance. In doves, the dark color of plumage

1 The writer is indebted to the Imperial Academy of Japan for a grant in aid of this work. The experimental results were reported partly before the Annual Grand Meetings of the Scientific Agricultural Society held in Tokio, 1931 and 1933. 
in the European turtle dove, Turtur turtur, (STAPLES-BRowne, 1912), that in the Japanese turtle dove, Tutur orientalis, (Whitman, 1919), and the blond color in the ring dove (the Barbary Dove), Streptopelia risoria, (Staples-Browne, 1912; Strong, 1912; WhitMan, 1919) have been shown to be sex-linked in transmission. As to the sex-linked inheritance of the blond plumage color in ring doves, which is the subject of this paper, WhitMan was perhaps the first investigator to make breeding experiments with blond and white ring doves, but his work was performed during several years (18961900) preceding the rediscovery of MENDEL's principles of heredity, and it was not adequate for us to get an exact idea on the sexlinked inheritance at that time; STAPI.Fs-BRowne made a contribution to this line of study, crossing blond ring doves with white ones, but his report was only a preliminary account; STRONG followed WhITMAN in this work and made comparatively extensive breeding experiments extending over a period of six years (19041910) and including three generations of doves, but according to him, the work was not sufficiently carried out because he could not find a suitable plant for the brceding of the birds; and since the sex of scarcely more than half the offspring was recorded, the data presented in the tables are unable to show whether the ratios diverge from expectation or not; furthermore this author does not accept the view that the doves are of poultry type (WZ-ZZ type) in relation to sex.

The writer, being interested in the sex studies in birds which are at present recognized to be reversible in sex (Crew, 1923; BeNort, 1923 ; Riddle, 1924; Zawadowsky, 1926; Domm, 1929) even in the post-natal stage, began breeding experiments with blond and white ring doves towards the end of the year 1927, to obtain more reliable data on the sex-linked inheritance of the plumage color than those which have hitherto been published. In the course of the experiments, furthermore, there unexpectedly occurred albino individuals in the offspring of blond ring doves, and this was previously reported by the present writer in 1932. The albino individuals breed true, and have established a new race of ring doves in the writer's aviary. With the albino ring doves were mated the blond and white ones, and it was discovered, from the hereditary interrelationship found to exist among these three races of ring doves, that the blond color of plumage, which is shown to be 
sex-linked in inheritance, is due to two factors, the one being autosomal and the other sex-linked.

\section{MATERIAL AND METHODS}

The ring doves used here are the two common species or races of cage ring doves, the blond ring dove, Streptopelia risoria, and the white ring dove, Streptopelia alba, purchased from a birdfancier towards the end of the year 1927, as well as the albino ring dove, which the writer regards as a new race produced in his own aviary. ${ }^{23}$

The total number of birds purchased as the original stock was 20 , of which 16 were blond ring doves $(\rho=8, \hat{0}=8$ ) and 4 were white ones $(9=3, d=1)$. The writer is convinced that these stock birds, except the four ( 9 AA 5, CAA 17, PAA 15, and $\therefore$ AA 12) from which the newly-found albino individuals descended (TANGE, 1932), are all genetically pure in plumage color, since there occurred no segregation in the offspring bred by close inbreeding throughout several generations. The data obtained from the crossing of any of the four birds mentioned above with other individuals are distinguished from the data of the crossing of other birds, as will be seen in the tables. The offspring of the other four birds ( AA 18, AA 14, AA 11, and AA 16) which were apparently in relation to the occurrence of the albino individuals as described in the previous paper (TANGE, 1932), were not excluded because it was found by subsequent breeding experiments that they were pure in respect of the blond plumage color.

1 According to SAlvipyz! (1893), the tame ring doves are of unknown ancestry, but the dark form is referred to the species Tutur risorius, subgenus Streptopelia. In SinkPe.'s Handlist (SHaRPI, 1899, p. 78) the term Streptopelia risoria Linn. is employed.

SAlVAbin (1893, p. 415) considered the white ring dove, Turtur alba, to be a white variety of Turtur risorius, though he mentions the fact that Temsinch and others have regarded the white bird as a distinct species. (Srrokc, 1912, p. 295;.

? There is, as Wimsan (1919) describes, another species of ring dove in Japan which is more reddish in plumage color and larger than the blond ring dove, named Streptopelia douraca by him, this kind of ring dove lives in a wild state in Saitama prefecture, and is not usually reared as a cage bird. This was not used in the present experiments. 
The brecding pairs were strictly separated, each in a single cage. ${ }^{1}$ Breeding records were kept by inspecting each cage twice a day in egg-laying, incubation, and rearing the squabs. Each egg laid was marked on the shell in pencil and weighed. When a squab from one of the clutch was hatched, a nail of the toe was cut to distinguish it from the other bird out of the other egg of the same clutch.

Although squabs on hatching have only scanty down, and although it is often hardly possible to predict by the down itself whether a squab will develop into a blond or a white dove, one can, at this early stage, distinguish decidedly the blond squab from the white one by inspecting the color at the region of the eyes, since the former has a dark appearance in this region, while the latter has a lighter or reddish color. The blond bird has plenty of dark pigment-granules in the iris, the ciliary processes, the pars ciliaris retinae, and the retina proper, as well as in the choroid and sclera, which give the darker appearance to the region as seen through the eyelids which are closed at the hatching time, while the white bird at the stage of nestling has pigment-granules in the iris, the ciliary processes, and the pars ciliaris retinae only, and apparently none in other parts. It is possible to make this macroscopic distinction even at the embryonic stage after about one week of incubation. Squabs of albino ring doves look like those of white ones, and it is impossible to discriminate between them by the external appearance of the region about the eyes; the iris itself must be examined. The iris of the squab of the white ring dove is dusky owing to the existence of the pigment-granules, and it makes a noticeable contour-line around the pupil which looks red; whereas the iris of the squab of the albino ring dove is light red just like the pupil, owing to the non-existence of the pigment-

I They were placed in pairs in cages of the size of $0.6 \times 1.2 \times 2.4$ meters. A nest-box of the size of $27 \times 18 \times 7 \mathrm{~cm}$. with hay or rice-straw was provided in each cage.

A mixed grain diet, kept quite uniform during many years and throughout all months of the year, was supplied in moderate excess to all birds. The grain mixture given was composed of millet and unpolished broken rice which is obtainable in the course of hulling rice. All birds were plentifully supplied with crushed oyster shell and grit as well as cold fresh water. 
granules, and there is no contour-line to separate clearly the two parts, the iris and the pupil. It is not possible to make this distinction between the white and the albino squabs macroscopically during the embryonic stage.

The color of plumage of a bird dead in the shell during the embryonic stage and older than one week of incubation was determined by the color appearing in the region of the eyes as mentioned above; and the sex was determined by the gonads found on dissection. If it was difficult to distinguish the testis from the ovary macroscopically, the tissue was fixed and close examination was made microscopically.

At the age of about two weeks after hatching, the birds were all tagged with leg-bands of alminium to distinguish the individuals. Squabs of over a month old (after hatching) were placed together in larger cages of the size of $2 \times 1.2 \times 2.4$ meters. Some of them were used in breeding experiments while others were killed after the time of sexual maturity and an autopsy was made of them.

The sex of each bird was ascertained by whether or not the bird had produced fertile eggs, or by dissection.

When the males were interchanged between two pairs, the eggs laid within ten days after the interchange were excluded because the stale sperms are liable to retain their fertilizing power in the oviduct of the female dove (RIDDLE and BEHRE, 1921).

\section{EXPERIMENTAL RESULTS}

\section{(I) Results of the Crossing of Blond Ring Doves with White Ones.}

When a white male is crossed to a blond female, the sons are blond like their mother and the daughters are white like their father, or crisscross inheritance. In the reciprocal cross, i.e., when a blond male is bred to a white female, the sons and daughters are all blond. Blond is dominant to white, though the blond hybrids, especially the male ones, have a slight tendency to be somewhat lighter in color than the blond parent. 
(a) $F_{1}$

\section{(A) Blond $\stackrel{9}{\times}$ White $s$}

\section{Table 1}

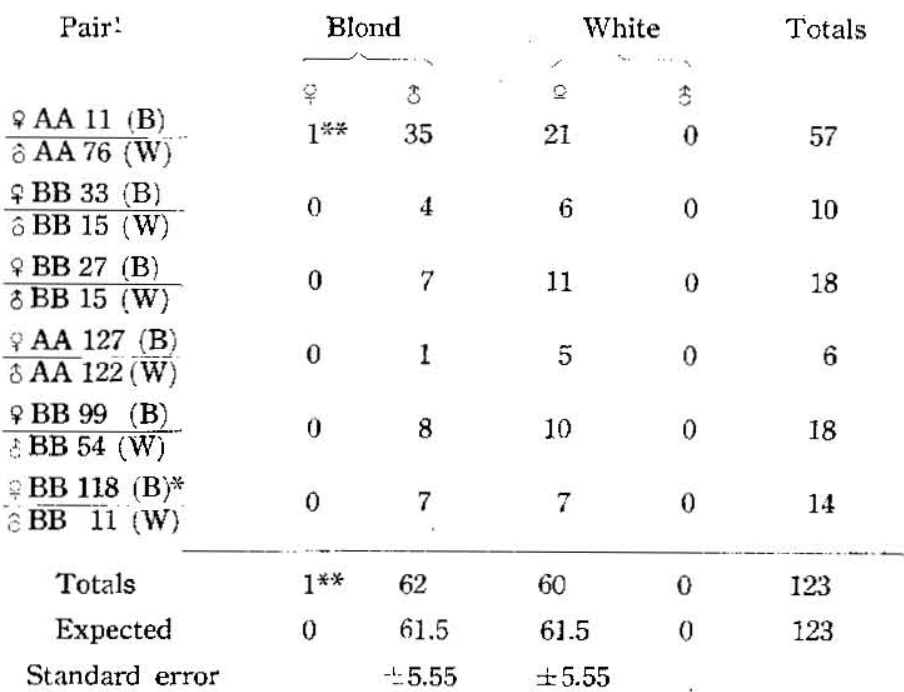

(b) $\mathrm{F}_{2}$

\section{Table 2}

\begin{tabular}{|c|c|c|c|c|c|}
\hline Pair & \multicolumn{2}{|c|}{ Blond } & \multicolumn{2}{|c|}{ White } & Totals \\
\hline & 3 & 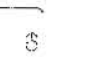 & $=$ & $\hat{\varepsilon}$ & \\
\hline $\begin{array}{l}\text { BB } 38(\text { H.W }) \\
\text { BB } 82(\text { H.B) }\end{array}$ & 18 & 18 & 15 & 10 & 61 \\
\hline$\frac{\mathrm{BB} \quad 64(\mathrm{H} . \mathrm{W})}{\mathrm{BB} 120(\mathrm{H} . \mathrm{B})}$ & 11 & 6 & 7 & 19 & 43 \\
\hline$\frac{7 \text { BB } 39}{8 \text { CC } 16}($ H.W $)$ & 10 & 8 & 12 & 16 & 46 \\
\hline$\frac{\text { BB } 86 \text { (H.W) }}{3 \text { CC } 38 \text { (H.B) }}$ & 10 & 8 & 13 & 10 & 41 \\
\hline 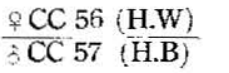 & 11 & 15 & 10 & 7 & 43 \\
\hline Totals & 60 & 55 & 57 & 62 & 234 \\
\hline Expected & 58.5 & 58.5 & 58.5 & 58.5 & 234 \\
\hline Standard error & +6.62 & $\because 6.62$ & $\therefore 6.62$ & $\therefore 6.62$ & \\
\hline
\end{tabular}

1 In all of the tabulated breeding records of this paper the individual number or formula for the female bird which was used as dam is written as the numerator and that for the male as the denominator of the fraction.

$\mathrm{B}=$ blond ; $\mathrm{W}=$ white ; $*$ Exceptional bird ;

* Bird which is related to the occurrence of albino individuals;

$\mathrm{H} . \mathrm{B}=$ hybrid blond; $\mathrm{H}$. $\mathrm{W}=$ hybrid white. 
(c) $\mathrm{F}_{3}$

\section{Table 3}

\begin{tabular}{|c|c|c|c|c|c|}
\hline \multirow{4}{*}{$\begin{array}{c}\text { Pair } \\
\frac{\text { †C } 172(\text { H.W })}{\delta \text { CC } 123 \text { (H.B) }}\end{array}$} & \multicolumn{2}{|c|}{ Blond } & \multicolumn{2}{|c|}{ White } & \multirow[t]{3}{*}{ Totals } \\
\hline & & - & & $\cdots$ & \\
\hline & $\mathcal{C}$ & $\hat{b}$ & q & $\hat{3}$ & \\
\hline & 8 & 12 & 8 & 4 & 32 \\
\hline Expected & 8.0 & 8.0 & 8.0 & 8.0 & 32 \\
\hline$\frac{9 \mathrm{CC} 122(\mathrm{H} . \mathrm{B})}{1 \mathrm{CC} 171(\mathrm{H} . \mathrm{W})}$ & 0 & 18 & 14 & 0 & 32 \\
\hline Expected & 0 & 16.0 & 16.0 & 0 & 32 \\
\hline$\frac{\text { CC } 185(\text { H.W })}{\hat{O C C ~} 184(\text { H.W })}$ & 0 & 0 & 16 & 16 & 32 \\
\hline Expected & 0 & 0 & 16.0 & 16.0 & 32 \\
\hline
\end{tabular}

An exceptional blond female occurred in $\mathrm{F}_{1}$ from blond female

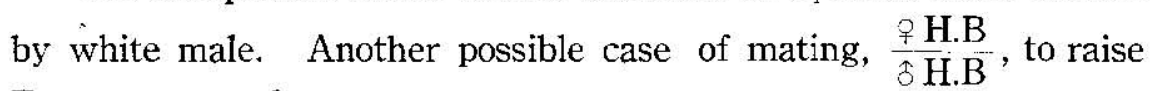
$F_{3}$ was not made.

(a) $\mathrm{F}_{1}$

(B) White $₹ \times$ Blond $\hat{c}$

\begin{tabular}{|c|c|c|c|c|c|}
\hline Pair & \multicolumn{2}{|c|}{ Blond } & \multicolumn{2}{|c|}{ White } & Totals \\
\hline & Q & $\hat{\beta}$ & क & $\hat{o}$ & \\
\hline$\frac{9 \text { AA } 71(\mathrm{~W})}{\hat{O} \mathrm{AA} 72}$ & 4 & 3 & 0 & 0 & 7 \\
\hline$\frac{\mathrm{AA} 70(\mathrm{~W})}{6 \mathrm{AA} 75}$ & 3 & 3 & 0 & 0 & 6 \\
\hline $\begin{array}{l}\text { AA } 79 \\
\text { AA } 6 \text { (W) }\end{array}$ & 1 & 1 & 0 & 0 & 2 \\
\hline$\frac{+\mathrm{BB} 52}{\mathrm{~s} A \mathrm{~A}} \frac{(\mathrm{W})}{(\mathrm{B})}$ & 14 & 19 & 0 & 0 & 33 \\
\hline$\frac{\% \mathrm{CC} 44(\mathrm{~W})}{\text { SAA } 103(\mathrm{~B})^{*}}$ & 4 & 4 & 0 & 0 & 8 \\
\hline$\frac{\text { B B } 5}{6 \text { AA } 21}-\frac{(W)}{(B)^{\circ}}$ & 4 & 8 & 0 & 0 & 12 \\
\hline$\frac{\mathrm{CC} 95}{\mathrm{AAA} 21}\left(\frac{\mathrm{W})}{\mathrm{B})^{*}}\right.$ & 3 & 6 & 0 & 0 & 9 \\
\hline Totals & 33 & 44 & 0 & 0 & 77 \\
\hline Expected & 38.5 & 38.5 & 0 & 0 & 77 \\
\hline Standard error & \pm 4.39 & \pm 4.39 & & & \\
\hline
\end{tabular}


(b) $\mathrm{F}_{2}$

\begin{tabular}{|c|c|c|c|c|c|}
\hline Pair & \multicolumn{2}{|c|}{ Blond } & \multicolumn{2}{|c|}{ White } & Totals \\
\hline & $\stackrel{\varphi}{T}$ & $\hat{o}$ & 우 & $\hat{0}$ & \\
\hline$\frac{\mathrm{BB} 24 \text { (H.B) }}{3 \mathrm{BB} 20 \text { (H.B) }}$ & 5 & 11 & 6 & 0 & 22 \\
\hline Expected & 5.5 & 11.0 & 5.5 & 0 & 22 \\
\hline Standard error & \pm 2.03 & $\llcorner 2.35$ & \pm 2.03 & & \\
\hline
\end{tabular}

AA $103 *$ and $\mathrm{AA} 21 *$ are the male parents of the albino individuals which occurred unexpectedly, but the experimental results obtained from the crossing of these birds with white ones were not excluded because they behave as if they are pure blond, in producing the $F_{1}$ generation, as shown in Table 23 and Section 5. b. (p. 188). No $F_{1}$ 's from these birds, however, were used in further breeding experiments.

The $\mathrm{F}_{3}$ generation was not raised in this case. The data recorded in Section D. b., which correspond to those of $F_{3}$, are presented to supplement the foregoing results.

Two kinds of genotype, homozygous and heterozygous, should exist among $\mathrm{F}_{2}$ blond males ex White $\hat{q} \times$ Blond $\hat{o}$. Experiments to distinguish them were not carried out, but the blond males bred from the matings shown in Section D. a. ii. correspond to the $\mathrm{F}_{2}$ blond males, and the data recorded in Section D. b. i. and Section $\mathrm{E}$ are to supplement the results presented in Tables 4 and 5 .

(C) Back Crossing

(a) Blond $\sim \times \mathrm{F}_{1}$ blond $\hat{\sigma}$ from Sections $\mathrm{A}$ and $\mathrm{B}$.

Table 6

\begin{tabular}{|c|c|c|c|c|c|}
\hline \multirow[t]{2}{*}{ Pair } & \multicolumn{2}{|c|}{ Blond } & \multicolumn{2}{|c|}{ White } & \multirow[t]{2}{*}{ Totals } \\
\hline & ? & 3 & 2 & $\hat{3}$ & \\
\hline $\begin{array}{l}\therefore \mathrm{BB} \quad \frac{8}{(\mathrm{~B})^{*}} \\
\mathrm{CCC}^{2}(\mathrm{H} \cdot \mathrm{B})\end{array}$ & 6 & 9 & 2 & 0 & 17 \\
\hline$\frac{2 \mathrm{BB} 72(\mathrm{~B})}{\mathrm{CC} 76(\mathrm{H} . \mathrm{B})}$ & 7 & 15 & 2 & 0 & 24 \\
\hline $\begin{array}{l}\text { BB } 21 \text { (B) } \\
\text { BB } 65 \text { (H.B) }\end{array}$ & 2 & 7 & 3 & 0 & 12 \\
\hline Totals & 15 & 31 & 7 & 0 & 53 \\
\hline Expected & 13.25 & 26.5 & 13.25 & 0 & 53 \\
\hline Standard error & \pm 3.15 & \pm 3.64 & \pm 3.15 & & \\
\hline
\end{tabular}




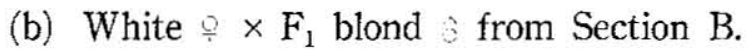

\begin{tabular}{|c|c|c|c|c|c|}
\hline \multirow[t]{2}{*}{ Pair } & \multicolumn{2}{|c|}{ Blond } & \multicolumn{2}{|c|}{ White } & Totals \\
\hline & $\ddot{4}$ & f & 7 & 3 & \\
\hline $\begin{array}{l}\text { QAA } 71 \text { (W) } \\
6 \mathrm{BB} 20(\mathrm{H} \cdot \mathrm{B})\end{array}$ & 3 & 1 & 3 & 4 & 11 \\
\hline Expected & 2.75 & 2.75 & 2.75 & 2.75 & 11 \\
\hline
\end{tabular}

is 76 (H.B) and $5 \mathrm{BB} 65$ (H.B) are the offspring $\left(\mathrm{F}_{1}\right)$ from Sections A and B, respectively; the latter was back-crossed to a pure blond $\odot$, i.e., $\mathrm{P}_{1}$ of Section $\mathrm{A}$, and this mating is not of true back crossing like the mating of the former to the blond $P$ 's but is merely corresponding to this, genotypically. They were treated here all alike for the sake of convenience.

BB $8(\mathrm{~B})^{*}$ is the female parent of the albino individuals, but the experimental results obtained from breeding it were not excluded just like those from the male parents in Table 4 .

The remaining possible matings of the back crossing, H.W from (A) and $\frac{\mathrm{H} . \mathrm{B} \text { from }(\mathrm{B})}{\mathrm{B}}$, were not made.

(D) Miscellaneous Crossing

(a) Corresponding to $\mathrm{F}_{2}$.

(i) $F_{1}$ white from Section $A \times F_{1}$ blond from Section $B$.

Table 8

\begin{tabular}{|c|c|c|c|c|c|}
\hline Pair & & & & & Totals \\
\hline & 2 & 3 & 2 & $\delta$ & \\
\hline$\frac{\mathrm{CC} 75(\mathrm{H} . \mathrm{W})}{\mathrm{B} B \mathrm{HB}(\mathrm{H})}$ & 9 & 8 & 7 & 7 & 31 \\
\hline Expected & 7.75 & 7.75 & 7.75 & 7.75 & 31 \\
\hline
\end{tabular}

(ii) $F_{1}$ blond from Section $B \times F_{1}$ blond from Section $A$. 
Table 9

\begin{tabular}{|c|c|c|c|c|c|}
\hline \multirow[t]{2}{*}{ Pair } & \multicolumn{2}{|c|}{ Blond } & \multicolumn{2}{|c|}{ White } & \multirow[t]{2}{*}{ Totals } \\
\hline & $\%$ & $\hat{c}$ & 9 & $\hat{o}$ & \\
\hline$\frac{\text { क BB } 85 \text { (H.B) }}{\delta \text { BB } 98(\text { H.B })}$ & 12 & 30 & 13 & 0 & 55 \\
\hline$\frac{\mathrm{BB} 83 \text { (H.B) }}{\mathrm{CCC} 18(\mathrm{H} . \mathrm{B})}$ & 14 & 18 & 9 & 0 & 41 \\
\hline Totals & 26 & 48 & 22 & 0 & 96 \\
\hline Expected & 24.0 & 48.0 & 24.0 & 0 & 96 \\
\hline Standard error & $=4.24$ & \pm 4.90 & $=4.24$ & & \\
\hline
\end{tabular}

(b) Corresponding to $\mathrm{F}_{3}$.

(i) $\mathrm{F}_{2}{ }^{1}$ white from Section D. a. ii. $\times \mathrm{F}_{2}{ }^{1}$ blond from Section D. a. ii.

\begin{tabular}{|c|c|c|c|c|c|}
\hline \multirow[t]{2}{*}{ Pair } & \multicolumn{2}{|c|}{ Blond } & \multicolumn{2}{|c|}{ White } & Totals \\
\hline & 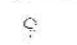 & 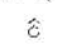 & $f$ & $\hat{\varepsilon}$ & \\
\hline$\frac{\mathrm{CC} 175(\mathrm{H} . W}{6 \mathrm{CC} 120(\mathrm{H} . \mathrm{B})}$ & 18 & 14 & 0 & 0 & 32 \\
\hline Expected & 16.0 & 16.0 & 0 & 0 & 32 \\
\hline
\end{tabular}

The data presented in Table 10 show that the bird $\mathrm{CC} 120$ (H.B) is to be regarded as a homozygous blond.

(ii) $\mathrm{F}_{2}{ }^{1}$ blond from Section D. a. ii. $\times \mathrm{F}_{2}$ white $\hat{0}$ from Section A.

Table 11

\begin{tabular}{|c|c|c|c|c|c|}
\hline Pair & \multicolumn{2}{|c|}{ Blond } & \multicolumn{2}{|c|}{ White } & Totals \\
\hline & $q$ & $\hat{o}$ & $\$$ & $\hat{\jmath}$ & \\
\hline$\frac{\text { CC } 47(\text { H.B })}{\text { CC } 171(\text { H.W })}$ & 0 & 2 & 1 & 0 & 3 \\
\hline Expected & 0 & 1.5 & 1.5 & 0 & 3 \\
\hline
\end{tabular}

1 Not true $F_{2}$ but corresponding to $F_{2}$. 
Sex-linked Inheritance of Plumage Color in the Ring Dove 171

(c) $F_{1}$ white $\times F_{2}$ blond 5 from Section $A$.

Table 12

\begin{tabular}{|c|c|c|c|c|c|}
\hline \multirow[t]{2}{*}{ Pair } & \multicolumn{2}{|c|}{ Blond } & \multicolumn{2}{|c|}{ White } & \multirow[t]{2}{*}{ Totals } \\
\hline & 9 & s & $\underline{2}$ & $\hat{0}$ & \\
\hline$\frac{\text { †B } 91(\text { H.W })}{\text { CC } 77(\text { H.B })}$ & 1 & 0 & 0 & 2 & 3 \\
\hline$\frac{\mathrm{BB} 121(\mathrm{H} . \mathrm{W})}{\mathrm{CC} 37(\text { H.B })}$ & 0 & 0 & 1 & 0 & 1 \\
\hline Totals & 1 & 0 & 1 & 2 & 4 \\
\hline Expected & 1.0 & 1.0 & 1.0 & 1.0 & 4 \\
\hline
\end{tabular}

(d) Back cross white of from Section C. a. $\times$ Blond $s$.

Table 13

\begin{tabular}{|c|c|c|c|c|c|}
\hline Pair & \multicolumn{2}{|c|}{ Blond } & \multicolumn{2}{|c|}{ White } & Totals \\
\hline & $\%$ & $\hat{o}$ & 7 & 3 & \\
\hline$\frac{\text { CC } 103(\text { H.B })}{3 \mathrm{AA} 103(\mathrm{~B})^{* *}}$ & 6 & 3 & 0 & 0 & 9 \\
\hline Expected & 4.5 & 4.5 & 0 & 0 & 9 \\
\hline
\end{tabular}

(e) $F_{1}$ blond $q$ from Section $B \times$ Back cross white $\hat{b}$.

Table 14

\begin{tabular}{|c|c|c|c|c|c|}
\hline Pair & \multicolumn{2}{|c|}{ Blond } & \multicolumn{2}{|c|}{ White } & Totals \\
\hline & 2 & o & 3 & $\hat{\sigma}$ & \\
\hline$\frac{\mathrm{BB} 66 \text { (H.B) }}{\mathrm{CC} 43(\mathrm{H} . \mathrm{W})}$ & 0 & 19 & 19 & 0 & 38 \\
\hline Expected & 0 & 19.0 & 19.0 & 0 & 38 \\
\hline
\end{tabular}

(f) Blond $\uparrow \times$ Back cross white $\hat{\jmath}$.

Table 15

\begin{tabular}{|c|c|c|c|c|c|}
\hline Pair & \multicolumn{2}{|c|}{ Blond } & \multicolumn{2}{|c|}{ White } & Totals \\
\hline & $\therefore$ & 3 & $\frac{3}{7}$ & 3 & \\
\hline$\frac{\mathrm{CC} 3}{\hat{\mathrm{CCC}} 97}(\mathrm{~B})$ & 0 & 1 & 1 & 0 & 2 \\
\hline$\frac{+C C 54 \quad(B)}{5 C C} 9 \overline{(H . W)}$ & 0 & 11 & 7 & 0 & 18 \\
\hline Totals & 0 & 12 & 8 & 0 & 30 \\
\hline Expected & 0 & 10.0 & 10.0 & 0 & 20 \\
\hline
\end{tabular}


(g) Back cross blond $\uparrow$ from Section C. b. $\times$ Back cross white $\hat{c}$. Table 16

\begin{tabular}{|c|c|c|c|c|c|}
\hline Pair & \multicolumn{2}{|c|}{ Blond } & \multicolumn{2}{|c|}{ White } & Totals \\
\hline & 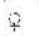 & 8 & i & $\hat{\varepsilon}$ & \\
\hline$\frac{\mathrm{CC} 24(\mathrm{H} . \mathrm{B})}{\mathrm{CCC} 96(\mathrm{H} . \overline{\mathrm{W}})}$ & 0 & 17 & 21 & 0 & 38 \\
\hline Expected & 0 & 19.0 & 19.0 & 0 & 38 \\
\hline
\end{tabular}

(h) Blond $\hat{\uparrow} \times \mathrm{F}_{2}$ white 6 from Section $\mathrm{A}$.

Table 17

\begin{tabular}{|c|c|c|c|c|c|}
\hline \multirow[t]{2}{*}{ Pair } & \multicolumn{2}{|c|}{ Blond } & \multicolumn{2}{|c|}{ White } & \multirow[t]{2}{*}{ Totals } \\
\hline & q & $t$ & $f$ & $\hat{b}$ & \\
\hline$\frac{\mathrm{BB} 27(\mathrm{~B})}{3 \mathrm{CC} 170(\mathrm{H} . \mathrm{W})}$ & 0 & 5 & 7 & 0 & 12 \\
\hline$\frac{\text { BB } 99(\mathrm{~B})}{6 \mathrm{DD} 198(\mathrm{H} . \mathrm{W})}$ & 0 & 12 & 9 & 0 & 21 \\
\hline Totals & 0 & 17 & 16 & 0 & 33 \\
\hline Expected & 0 & 16.5 & 16.5 & 0 & 33 \\
\hline
\end{tabular}

(E) To Distinguish the Homozygous Blond Males from the Heterozygous Ones in Section D. a. ii., which Correspond to $\mathrm{F}_{2}$

(a) Homozygous blond male. (Cf. Section D. b. i.).

(b) Heterozygous blond males from Section D. a. ii.

Table 18

\begin{tabular}{|c|c|c|c|c|c|}
\hline \multirow[t]{2}{*}{ Pair } & \multicolumn{2}{|c|}{ Blond } & \multicolumn{2}{|c|}{ White } & \multirow[t]{2}{*}{ Totals } \\
\hline & c & 3 & 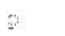 & s & \\
\hline$\frac{G \mathrm{CC} 132}{\hat{0} \mathrm{CC} 126}(\mathrm{~W})$ & 3 & 1 & I & 1 & 6 \\
\hline$\frac{\text { BB } 91}{\text { OCC } 82} \frac{\text { (H.W) }}{(\text { H.B })}$ & 0 & 2 & 1 & 1 & 4 \\
\hline Totals & 3 & 3 & 2 & 2 & 10 \\
\hline Expected & 2.5 & 2.5 & 2.5 & 2.5 & 10 \\
\hline
\end{tabular}


The data presented in the above table show that these males are to be regarded as heterozygous blond.

(II) Results of the Crossing of White or Albino Ring Doves with Blond Ones Related to the Occurrence of Albino Individuals, and Further Data on the Albino Ring Dove.

(a) Female parent (blond) of albino $\times$ Hybrid blond or White $\vdots$.

Table 19

\begin{tabular}{|c|c|c|c|c|c|c|c|}
\hline Pair & \multicolumn{2}{|c|}{ Blond } & \multicolumn{2}{|c|}{ White } & \multicolumn{2}{|c|}{ Albino } & \multirow[t]{2}{*}{ Totals } \\
\hline & 7 & $\hat{o}$ & $\because$ & $\hat{o}$ & ? & $\hat{0}$ & \\
\hline 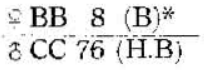 & 6 & 9 & 2 & 0 & 0 & 0 & 17 \\
\hline Expected & 4.25 & 8.5 & 4.25 & 0 & 0 & 0) & 17 \\
\hline$\frac{\mathrm{BB} 118(\mathrm{~B})^{*}}{\mathrm{BB}-11(\mathrm{~W})}$ & 0 & 7 & 7 & 0 & 0 & 0 & 14 \\
\hline Expected & 0 & 7.0 & 7.0 & 0 & 0 & 0 & 14 \\
\hline
\end{tabular}

(b) Albino $\simeq \times$ Its male parent (blond), (back crossing).

Table 20

\begin{tabular}{|c|c|c|c|c|c|}
\hline \multirow[t]{3}{*}{ Pair } & \multicolumn{2}{|c|}{ Blond } & \multicolumn{2}{|c|}{ Albino } & \multirow[t]{3}{*}{ Totals } \\
\hline & $\ldots$ & $\because$ & .. & & \\
\hline & 2 & $\hat{\sigma}$ & 2 & $\hat{3}$ & \\
\hline $\begin{array}{l}+\mathrm{CC} 215(\mathrm{~A}) \\
\mathrm{BB} 21(\mathrm{~B})\end{array}$ & 1 & 4 & 4 & 1 & 10 \\
\hline 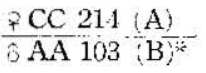 & 2 & 1 & 1 & 2 & 6 \\
\hline Totals & 3 & 5 & 5 & 3 & 16 \\
\hline Expected & 4.0 & 4.0 & 4.0 & 1.0 & 16 \\
\hline
\end{tabular}

(c) (i) Further data on the albino individuals raised out of the four pairs described in the previous paper (TANGE, 1932).

$A=$ albino. 


\begin{tabular}{|c|c|c|c|c|c|}
\hline \multirow[t]{2}{*}{ Pair } & \multicolumn{2}{|c|}{ Table 2} & \multicolumn{2}{|c|}{ Albino } & \multirow[t]{2}{*}{ Totals } \\
\hline & $\oiiint$ & $\hat{o}$ & $\mathrm{~g}$ & $\hat{\jmath}$ & \\
\hline No. $42 \frac{\mathrm{BB}}{3 \mathrm{AA}} 103 \frac{(\mathrm{B})^{*}}{(\mathrm{~B})^{*}}$ & 13 & 10 & 4 & 7 & 34 \\
\hline No. $3 \frac{q \mathrm{BB} 118(\mathrm{~B})^{*}}{\delta \mathrm{AA} 21(\mathrm{~B})^{*}}$ & 11 & 6 & 7 & 3 & $2 \bar{i}$ \\
\hline No. $31 \frac{2 \mathrm{AA} 110(\mathrm{~B})^{*}}{3 \mathrm{BB}} 10\left(\mathrm{~B}^{*}\right.$ & 20 & 14 & 3 & 4 & 41 \\
\hline 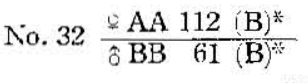 & 15 & 12 & 2 & 4 & 33 \\
\hline \multirow[t]{2}{*}{ Totals } & 59 & 42 & 16 & $18^{1}$ & 135 \\
\hline & \multicolumn{2}{|c|}{101} & \multicolumn{2}{|c|}{34} & \\
\hline \multirow[t]{3}{*}{ Expected } & $500_{0}^{5}$ & $50 \frac{5}{8}$ & $166_{\pi}^{\pi}$ & 16 & 135 \\
\hline & \multicolumn{2}{|c|}{101.25} & \multicolumn{2}{|c|}{33.75} & \\
\hline & \multicolumn{2}{|c|}{3} & \multicolumn{2}{|c|}{1} & \\
\hline Standard error & $\because 5.6$ & $\therefore 5.63$ & $=3.84$ & $=3.84$ & \\
\hline
\end{tabular}

(ii) Results of the pure breeding of albino ring doves.

Table 22

\begin{tabular}{ccc} 
Pair & \multicolumn{2}{c}{ Albino } \\
DD 323 (A) & 9 & of \\
\hline CD 202 (A) & 9 & 10 \\
Expected & 9.5 & 9.5
\end{tabular}

(d) White $\& \times$ Male parent (blond) of albino.

1 No albino male was reported in the previous paper (Tange, 1932), but, from the subsequent breeding, both sexes of albinos were produced in approximately equal numbers. 
Table 23

\begin{tabular}{|c|c|c|c|c|c|c|c|}
\hline Pair & \multicolumn{2}{|c|}{ Blond } & \multicolumn{2}{|c|}{ White } & \multicolumn{2}{|c|}{ Albino } & Totals \\
\hline & 4 & $\hat{3}$ & \% & s & 2 & 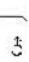 & \\
\hline$\frac{\mathrm{BB} 5(\mathrm{~W})}{\mathrm{AA} 21(\mathrm{~B}) \%}$ & $\frac{1}{4}$ & 8 & 0 & 0 & 0 & 0 & 12 \\
\hline $\begin{array}{l}\text { CC } 95(\mathrm{~W}) \\
3 \mathrm{AA} 21(\mathrm{~B})^{*}\end{array}$ & 3 & 6 & 0 & 0 & 0 & 0 & 9 \\
\hline$\frac{\mathrm{AA} \quad 71(\mathrm{~W})}{\hat{\mathrm{J} A A} 103(\mathrm{~B})^{*}}$ & 0 & 1 & 0 & 0 & 1) & 0 & 1 \\
\hline$\frac{\mathrm{CC}}{4 \mathrm{AA}} 103(\mathrm{~W})$ & 4 & 4 & 0 & 0 & 0 & 0 & 8 \\
\hline$\frac{\mathrm{CC} 103(\mathrm{H} . \mathrm{W})}{\mathrm{AAA} 103(\mathrm{~B})^{*}}$ & 6 & 3 & 0 & 0 & 0 & 0 & 9 \\
\hline 'Totals & 17 & 22 & 0 & 0 & 0 & 0 & 39 \\
\hline Expected & 19.5 & 19.5 & 0 & 0 & 0 & 0 & 39 \\
\hline
\end{tabular}

\section{(III) Results of the Crossing of Albino Ring Doves with White Ones.}

(a) White $\times$ Albino

Table 24

\begin{tabular}{|c|c|c|c|c|c|c|c|}
\hline \multirow[t]{2}{*}{ Pair } & \multicolumn{2}{|c|}{ Blond } & \multicolumn{2}{|c|}{ White } & \multicolumn{2}{|c|}{ Albino } & Totals \\
\hline & $=$ & $\hat{3}$ & $\hat{\imath}$ & $\hat{\Xi}$ & + & $\hat{8}$ & \\
\hline$\frac{C C 95(W)}{D D 62(B)}$ & 7 & 8 & 0 & 0 & 0 & 0 & 15 \\
\hline $\begin{array}{lr}\mathrm{CC} & 95(\mathrm{~W}) \\
\mathrm{EE} & 114\end{array}$ & 4 & 1 & 0 & 0 & 1) & 0 & 8 \\
\hline $\begin{array}{l}\mathrm{BB} \\
\mathrm{B}\end{array}$ & 3 & 2 & 0 & 0 & 0 & 0 & 5 \\
\hline$\frac{7 \mathrm{CC} 185(\mathrm{H} . \mathrm{W})}{6 \mathrm{EE} \quad 32-(\mathrm{A})}$ & 1 & 3 & 0 & 0 & D & 0 & 4 \\
\hline Totals & 15 & 17 & 0 & 0 & 0 & 0 & 32 \\
\hline Expected & 16.0 & 16.0 & 0 & 0 & 0 & 3 & 32 \\
\hline
\end{tabular}




\begin{tabular}{|c|c|c|c|c|c|c|c|}
\hline \multirow[b]{3}{*}{$\frac{\mathrm{CC} 214(\mathrm{~A})}{\mathrm{B} B \quad 54(\mathrm{~W})}$} & \multicolumn{2}{|c|}{ Blond } & \multicolumn{2}{|c|}{ White } & \multicolumn{2}{|c|}{ Albino } & \multirow[t]{2}{*}{ Totals } \\
\hline & $\stackrel{0}{q}$ & 3 & q & f & $\bar{p}$ & 0 & \\
\hline & 0 & 16 & 11 & 0 & 0 & 0 & 27 \\
\hline$\frac{9 \mathrm{CC} 215(\mathrm{~A})}{\mathrm{a} B(11(\mathrm{~W})}$ & 0 & 4 & 5 & 0 & 0 & 0 & 9 \\
\hline$\frac{q \mathrm{CC} 215(\mathrm{~A})}{8 \mathrm{CC} 96(\mathrm{H} . \mathrm{W})}$ & 0 & 3 & 3 & 0 & 0 & 0 & 6 \\
\hline Totals & 0 & 23 & 19 & 0 & 0 & 0 & 42 \\
\hline Expected & 0 & 21.0 & 21.0 & 0 & 0 & 0 & 42 \\
\hline
\end{tabular}

We will consider first the experimental results of the crossing of blond ring doves with white ones.

(l) $F_{1}$ and $F_{2}$. The results shown in Tables $1,2,4$, and 5 may be interpreted by the following scheme of inherinance:

(A)

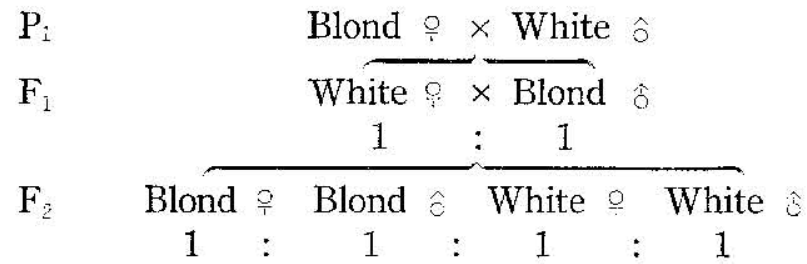

(B)

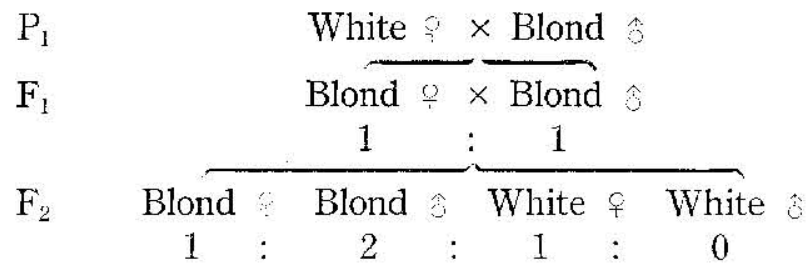

This is the same scheme as that in the inheritance of the barring in the domestic fowl (MokGan, 1919). So far as the experimental results mentioned above are concerned, the factor or gene for blond plumage color is a single one just like that for barring in the fowl, and it is regarded as being carried by the Z-chromosome. And the chromosomal explanation can be worked out on the following scheme, $B$ being the factor for blond: 


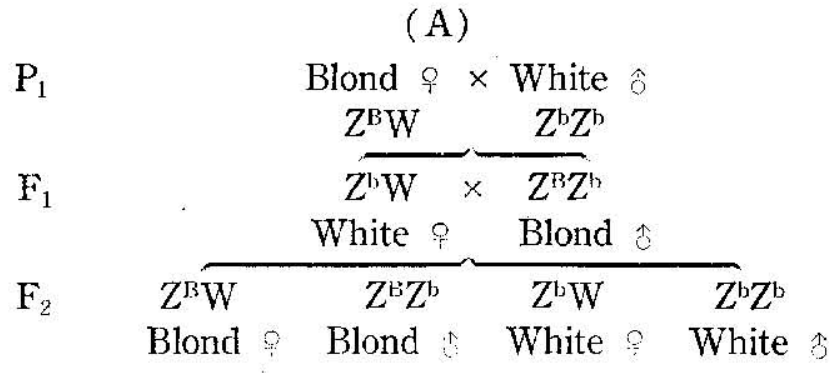

(B)

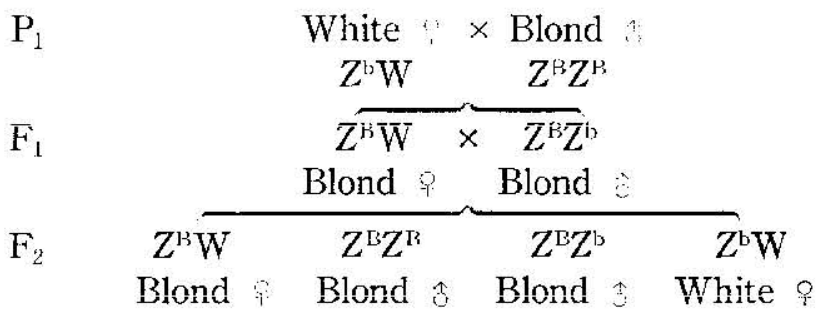

As is shown in Tables 1 and 2, the actual numbers are not far from the theoretical ones calculated upon the above scheme; the deviations do not exceed three times the standard errors. Of the "exceptional" bird in Table 1 consideration will be made later (p. 182). In Tables 4 and 5, the actual numbers are near to the theoretical ones, although the number of progeny is not large. Supplementing the data presented in Table 5 , experiments shown in Table 9 were made, since the $\mathrm{F}_{1}$ blond males $e x$ White $? \times$ Blond are of the same genotype as those ex Blond $? \times$ White 1 , as is shown in the above scheme of inheritance, i.e., $Z^{\mathrm{B}} \mathrm{Z}^{\mathrm{b}}$. Combining the data shown in Table 5 with those in Table 9, the following results are obtained:

\begin{tabular}{|c|c|c|c|c|c|}
\hline \multirow[t]{2}{*}{ Tabie } & \multicolumn{2}{|c|}{ Blond } & \multicolumn{2}{|c|}{ White } & \multirow[t]{2}{*}{ Totals } \\
\hline & q & 3 & 2 & $\hat{\alpha}$ & \\
\hline 5 & 5 & 11 & 6 & 0 & 22 \\
\hline 9 & 26 & 48 & 22 & 0 & 96 \\
\hline Totals & 31 & 59 & 28 & 0 & 118 \\
\hline Ixpected & 29.5 & 59.0 & 29.5 & 0 & 118 \\
\hline Standard error & $\therefore 4.70$ & +5.43 & $\therefore 4.70$ & & \\
\hline
\end{tabular}


The results shown in the above table represent a better agreement when compared with the theoretical figures.

(2) $\mathrm{F}_{3}$. (i) The $\mathrm{F}_{3}$ 's $e x$ Blond $9 \times$ White $s$ are to be raised out of four cases of mating $\mathrm{F}_{2}$ 's together, viz., $\frac{\text { + } \mathrm{H} . \mathrm{W}}{\mathrm{s} . \mathrm{B}}, \frac{+\mathrm{H} . \mathrm{B}}{\mathrm{H} . \mathrm{B}}$,

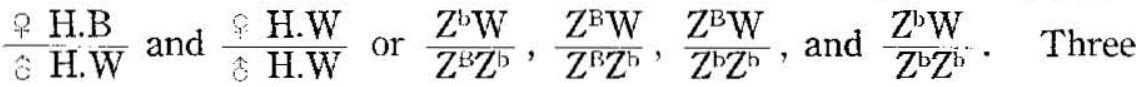
matings out of four, excepting $\frac{Z^{\mathrm{B}} W}{Z^{\mathrm{B}} Z^{\mathrm{b}}}$, were made, and the results obtained are in agreement with the theoretical expectation though the numbers secured are not large. (ii) $\mathrm{F}_{3}$ 's $e x$ White $q \times$ Blond $\$$ are to be raised out of two cases of the mating, viz., $\frac{\uparrow \mathrm{H} . \mathrm{B}}{\mathrm{H} . \mathrm{B}}$ and $\frac{\text { H.W }}{\mathrm{H} . \mathrm{B}}$, phenotypically. But since there should be two kinds of S H.B different genotypically from each other, it was possible to make four matings in this case, too, viz., $\begin{aligned} & Z^{\mathrm{B}} \mathrm{W} \\ & Z^{\mathrm{r}} Z^{\mathrm{B}}\end{aligned}, \begin{aligned} & Z^{\mathrm{s}} \mathrm{W} \\ & Z^{\mathrm{B}} Z^{\mathrm{b}}\end{aligned}, Z_{Z^{\mathrm{B}}}^{Z^{\mathrm{b}}}$, and $\frac{Z^{b} W}{Z^{b} Z^{b}}$. We have no experimental results of true $F_{3}$; but from the results presented in Tables 10 and 11, which correspond to those of $\mathrm{F}_{3}$, we can see that there is a homozygous blond male which is to be designated as $Z^{B} Z^{B}$ in the progeny from $F_{1}$ blond $? \times F_{1}$ blond and that + H.B may be designated as $Z^{\mathrm{b}} \mathrm{W}$, since the types secured in Table 11 are as expected, although the numbers securcd are not large. The results presented in Table 18 show that there are heterozygous blond males which are to be designated as $Z^{\mathrm{e}} Z^{\mathrm{l}}$ in the progeny raised from the mating of $\mathrm{F}_{1}$ blond $+\times \mathrm{F}_{1}$ blond 3 . The ratio of the number of individuals of the homozygous blond males to that of the heterozygous ones was not determined in the present experiments.

(3) Back crossing. The possible cases of mating in the back crossing are as follows :

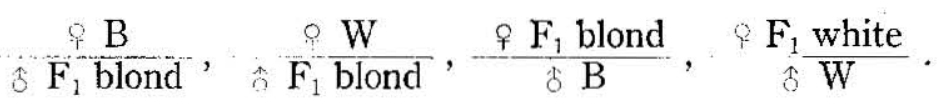

The experimental results were obtained from the first two matings out of four cases mentioned above. The number of progeny here is small, but the types secured are as expected.

(4) Other cases. The results described in Tables 12, 13, 14, 
15,16 , and 17 are from the miscellaneous crossing, and the actual numbers are all near to the theoretical ones in these cases, too.

(5) Summary of the results. (i) The total number of individuals handled in the crossing between the blond and white ring doves is 930, but numerous varieties of crossing often give us figures representing relatively small numbers of individuals; the actual numbers, however, are not far from the theoretical expectation in every case, with the single exception of the so-called "exceptional" bird. And consequently, the assumption that the blond ring doves are to be denoted by the formulæ $Z^{\mathrm{B} W}(\%)$ and $Z^{\mathrm{B}} Z^{\mathrm{B}}(b)$, and the white ones by $Z^{b} W(C)$ and $Z^{b} Z^{b}(\hat{b}), B$ being dominant to $b$, will account for the experimental results of the various cases of mating. (ii) If this assumption be correct, various forms of the foregoing crossing may be classified genotypically in the five cases of mating as follows :
(a) $Z_{Z^{\mathrm{B}} \mathrm{W}}^{\mathrm{b}}$
(b) $\begin{aligned} & Z^{\mathrm{B}} \mathrm{W} \\ & \mathrm{Z}^{\mathrm{b}} \mathrm{Z}^{\mathrm{b}}\end{aligned}$
(c) $\frac{Z^{b} W}{Z^{b} Z^{b}}$,
(d) $\frac{\mathrm{Z}}{\mathrm{Z}} \mathrm{W}$
(e) $\frac{Z^{\circ} W}{Z^{b} Z^{\circ}}$

Now we will collect the results of the foregoing experiments under these 5 cases.

\begin{tabular}{|c|c|c|c|c|c|c|}
\hline \multirow[t]{2}{*}{ Mating } & \multirow[t]{2}{*}{ No. of Table } & \multicolumn{2}{|c|}{ Blond } & \multicolumn{2}{|c|}{ White } & \multirow[t]{2}{*}{ Totals } \\
\hline & & 9 & $\hat{o}$ & 9 & $\therefore$ & \\
\hline \multirow[t]{3}{*}{ (a) } & 5 & 5 & 11 & 6 & 0 & \\
\hline & 6 & 15 & 31 & 7 & 0 & \\
\hline & 9. & 26 & 48 & 22 & 0 & \\
\hline \multicolumn{2}{|c|}{ Totals } & 45 & 90 & 35 & 0 & 171 \\
\hline \multicolumn{2}{|c|}{ Expected } & 42.75 & $85 . \overline{5}$ & 42.75 & 0 & 171 \\
\hline \multicolumn{2}{|c|}{ Standard error } & 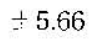 & \pm 6.54 & -15.66 & & \\
\hline \multirow[t]{7}{*}{ (b) } & 1 & $1^{* *}$ & 62 & 60 & 0 & \\
\hline & 3 & 0 & 18 & 14 & 0 & \\
\hline & 11 & 0 & 2 & 1 & 0 & \\
\hline & 14 & 0 & 19 & 19 & 0 & \\
\hline & 15 & 0 & 12 & 8 & 0 & \\
\hline & 16 & 0 & 17 & 21 & 0 & \\
\hline & 17 & 0 & 17 & 16 & 0 & \\
\hline \multicolumn{2}{|c|}{ Totals } & $1^{* * *}$ & 147 & 139 & 0 & 287 \\
\hline & sected & 0 & 143.5 & 143.5 & 0 & 287 \\
\hline \multicolumn{2}{|c|}{ Standard error } & & $\stackrel{-1}{-} 8.47$ & -8.47 & & \\
\hline
\end{tabular}




\begin{tabular}{|c|c|c|c|c|c|c|}
\hline \multirow[t]{3}{*}{ (c) } & 4 & 33 & 44 & 0 & 0 & \\
\hline & 10 & 18 & 14 & 0 & 0 & \\
\hline & 13 & 6 & 3 & 0 & 0 & \\
\hline \multicolumn{2}{|c|}{ Totals } & 57 & 61 & 0 & 0 & 118 \\
\hline \multicolumn{2}{|c|}{ Expected } & 59.0 & 59.0 & 0 & 0 & 118 \\
\hline \multicolumn{2}{|c|}{ Standard error } & $\doteq 5.43$ & . 5.43 & & & \\
\hline \multirow[t]{7}{*}{ (d) } & 2 & 60 & 55 & 57 & 62 & \\
\hline & 3 & 8 & 12 & 8 & 4 & \\
\hline & 7 & 3 & 1 & 3 & 4 & \\
\hline & 8 & 9 & 8 & 7 & 7 & \\
\hline & 12 & 1 & 0 & 1 & 2 & \\
\hline & 18 & 3 & 1 & 1 & 1 & \\
\hline & 18 & 0 & 2 & I & 1 & \\
\hline \multicolumn{2}{|c|}{ Totals } & 84 & 79 & 78 & 81 &, 322 \\
\hline \multicolumn{2}{|c|}{ Expected } & 80.5 & 80.5 & 80.5 & 80.5 & 322 \\
\hline \multicolumn{2}{|c|}{ Standard error } & \pm 7.77 & $\therefore 7.77$ & $\therefore 7.77$ & $\therefore 7.77$ & \\
\hline (e) & 3 & 0 & 0 & 16 & 16 & 32 \\
\hline & ted & 0 & 0 & 16.0 & 16.0 & 32 \\
\hline
\end{tabular}

It is seen, from the results shown in the above table, that the actual numbers obtained are in agreement with the theoretical ones with the single exception of one blond female from the mating (b).

The sex-ratio calculated from the numbers presented in the above table is $104:$ o 100 , the males being 474 and the females 456.

(6) Whitman (1919) performed breeding experiments with blond and white ring doves during several years (1896-1900) preceding the time of the rediscovery of MendeL's law of heredity. The results of his experiments may be tabulated as follows: 
Table 28

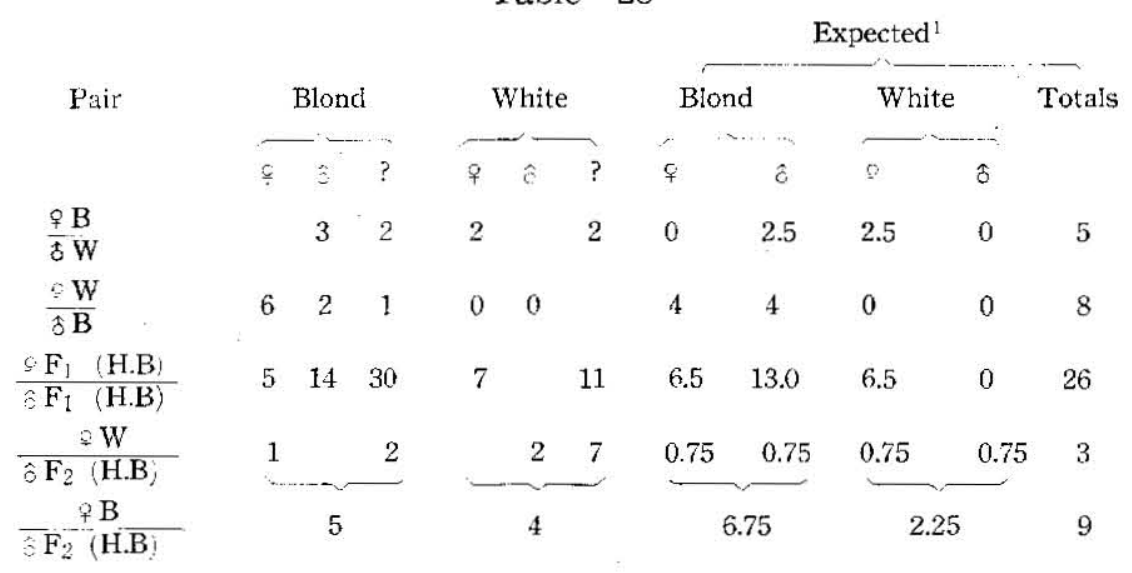

WHITMAN explained that crosses of these two kinds of ring doves involve a sex-linked inheritance of white color and an approach to a similar limitation upon the inheritance of blond color.

This breeding work was, according to RIDDLE, not all carried out along Mendelian lines, but in order to know the degree of the fertility of the doves and other physiological relationships, and consequently, it is not adequate to get an exact idea of the sexlinked inheritance of the blond or white color of plumage. But there exist no data conflicting with the assumption of the hereditary scheme previously described. On the contrary, if we exclude the figures denoting the number of individuals which are unknown in sex, and this exclusion is logically permissible since the selection of individuals to determine the sex was perhaps done at random, the data show that most of the experimental results are not far from the theoretical expectation, as recorded in Table 28.

(7) StAAPLES-BRowne (1912) raised $50 \mathrm{~F}_{1}$ 's by crossing blond ring doves (the Barbary Doves) with white ones (the White Java Dove), 36 ex Blond : $\times$ White ô and 14 ex White $\varrho \times$ Blond $\subseteq$. 15 ex White $\times$ Blond 0 were excluded by the present writer because the blond w was not pure (homozygous) according to the author. The data are as follows:

$?=$ unknown; 1 Expected, excluding the birds of unkown sex. 


\begin{tabular}{|c|c|c|c|c|c|}
\hline \multirow[t]{2}{*}{ Pair } & \multicolumn{2}{|c|}{ Dark (blond) } & \multicolumn{2}{|c|}{ White } & \multirow[t]{2}{*}{ Totals } \\
\hline & P & 3 & ? & $\hat{a}$ & \\
\hline $\begin{array}{l}¥ \text { Barbary Dove } \\
\text { White Java Dove }\end{array}$ & $1^{* * *}$ & 18 & 17 & 0 & 36 \\
\hline $\begin{array}{l}\text { White Java Dove } \\
\text { Barbary Dove }\end{array}$ & 7 & 7 & 0 & 0 & 14 \\
\hline
\end{tabular}

These results are just like those shown in Tables 1 and 4 in the present paper. STAPLES-BROWNE concluded: "The foregoing experiments are sufficient to show that a sex-limited inheritance of white ${ }^{1}$ occurs in the races of doves under consideration." "The occurrence of a dark female from $F_{1}$ is exceptional, and further work is required to explain its appearance." This exceptional bird is quite similar to that shown in Table 1 , consideration of which will be made further on.

(8) The data presented by STRoNG (1912) are full of varieties and are almost sufficient to prove the existence of sex-linkage in the blond color of plumage. But, unfortunately, he could not ascertain the sexes of 77 birds out of 151 which is the total number of birds he treated in his experiments, and consequently, the ratios of various forms among the offspring from the different matings can not be determined with certainty from the tables; furthermore, STRONG does not accept the view that ring doves belong to the poultry type in relation to sex, but the experimental results obtained by the writer are sufficient to confirm the fact of female heterogamety or poultry type in ring doves. OGUMA (1927) proved cytologically the female heterogamety in the domestic pigeon.

(9) Now we come to consider the "exceptional" bird, i.e., the blond female $e x$ Blond \& $\times$ White 5 . This "exceptional" bird in the writer's aviary occurred in the progeny of the pair AA $11(\mathrm{~B})$, and was hatched on Jan. 20, 1931 from the sccond egg of a clutch, laid on Jan. 6. This bird had been reared normally during nestling stage but died on Feb. 12 . Since the plumage color was blond, the writer was confident that it should be a male, on the contrary, it was found on autopsy to be a female; the left ovary and the left oviduct were found, the tissues were fixed and

i Stame-Bkin: regarded the white color of plumage as a sex-linked character. 
examined under microscope. No abnormality was recognized in other parts. The writer regrets that it died before reaching sexual maturity, when its genetic characters could have been examined. As it was, no further data are available on the bird.

STAPLES-BROWNE described one such exceptional bird raised out of three pairs of Blond $a \times$ White $\sigma$. The data are presented in Table 29 in this paper. STRong presented the data of three such birds. They were found among 18 blond and 23 white offsping produced from the 7 matings of Blond $q \times$ White $\hat{o}$. Out of 18 blonds, 7 were males, 3 females, and 8 unsexed; and out of 23 whites, 13 were females and 10 unsexed; hence there were 3 blond females out of 18 . This rate of occurrence is, in the writer's opinion, too high to recognize them as "exceptional" birds identical with those which were found by STAPLEs-Browne and the present writer. There is no such bird found in the data presented by WHITMAN.

StAPles-BRowNe has published, so far as the writer is aware, no experimental results on the "exceptional" bird, and the present writer did not succeed in raising the bird until it reached sexual maturity. And consequently, no genetic explanation is possible. But he suggests that the occurrence of the "exceptional" bird might be explained genetically as a case of non-disjunction. We may also suppose it physiologically to be a case of pre-natal sexreversal, but a male-to-female reversal has not yet been reported in birds. TANAKA (1924), on the other hand, reported the occasional appearance of exceptional individuals in the course of his experiments on the sex-linked inheritance in the silkworm, which resembles, in a hereditary sense, the occurrence of the "exceptional " birds, and he concluded from the results of exhaustive genetic experiments that it was due to mere somatic variation and not due to any genetic irregularities. Further investigations are necessary to determine whether or not the blond color of plumage in the ring dove appears as an aberrant white due to somatic variation.

(10) Summary of the foregoing descriptions. (i) The blond color of plumage in the ring dove is a sex-linked character, the male being homogametic and the female heterogametic. (ii) The blond and the white ring doves differ by a one-factor difference, viz., blond being $Z^{B}$ and its normal recessive allelomorph $Z^{\text {b }}$, so far 
as the experimental results obtained from the crossing between the blond and white ring doves concern. (iii) It is worthwhile to pay attention to the "exceptional" blond female bred out of the mating of a blond female with a white male, in the studies on sex of this species of bird.

We will consider next the experimental results of the crossing of white or albino ring doves with blond doves related to the occurrence of albino individuals, and further the crossing of albino ring doves with white ones, following the sequence of experiments carried on.

(1) The results of the crossing of the female parents (blond) of albino individuals with white or hybrid blond males confirm the hypothesis that the genetic constitution of the female parents of albino birds is to be designated as $Z^{\mathrm{B} W}$, since the following results are to be expected:

$$
\begin{aligned}
& \begin{array}{l}
\mathrm{BB} 8(\mathrm{~B})^{*} \\
\mathrm{CC} 76(\mathrm{H} \cdot \mathrm{B})^{-}
\end{array}=\frac{\mathrm{Z}^{\mathrm{b}} \mathrm{W}}{\mathrm{Z}^{\mathrm{B}} Z^{\mathrm{b}}} \rightarrow \mathrm{Z}^{\mathrm{B} W}, \quad Z^{\mathrm{B}} Z^{\mathrm{B}}, \quad Z^{\mathrm{B}} Z^{\mathrm{b}}, \quad Z^{\mathrm{b} W} ; \\
& \text { S } \mathrm{CC} 76(\mathrm{H} . \mathrm{B}) \quad Z^{\mathrm{B}} Z^{\mathrm{b}} \rightarrow \text { blond blond } 3 \text { blond } \hat{\mathrm{s}} \text { white }+7 \\
& \frac{\mathrm{BB} 118(\mathrm{~B})^{*}}{\mathrm{~s} \mathrm{~W}}=Z^{\mathrm{b} W} \rightarrow \begin{array}{c}
Z^{\mathrm{b}} Z^{\mathrm{b}}, \\
Z^{\mathrm{b}} Z^{\mathrm{b}}
\end{array} \rightarrow \begin{array}{c}
Z^{\mathrm{b}} \mathrm{W} . \\
\text { blond }
\end{array} \text { (Cf. Table 19). }
\end{aligned}
$$

These are the same types as (a) and (b) in Table 27 , respectively.

(2) The male parents of the albino individuals, however, are not adequately denoted by the formula $Z^{\mathrm{B}} Z^{3}$ or $Z^{\mathrm{B}} Z^{\mathrm{a}}$, which corres. ponds to that for females, $Z^{\mathrm{B}} W$. Thus :

(i) From the experimental results shown in Table 20, we can see that the two characters blond and albino form an allelomorphic pair, and since the blond color is a sex-linked character as previously described, we can denote the male parents (blond) of the ablino individuals by the formula $Z^{\mathrm{B} Z}$, where $B=$ blond, $a=$ albino, and $B$ is dominant to $a$. And consequently, the following scheme is to be expected:

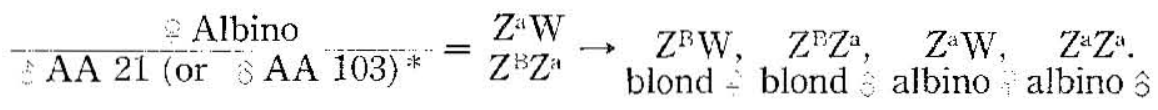

This agrees with the results shown in Table 20. But, since the genetic constitution of the female parents of albino individuals is $\mathrm{Z}^{\mathrm{B}} \mathrm{W}$, as mentioned above, and that of the male parents is $Z^{\mathrm{B}} \mathrm{Z}^{\mathrm{a}}$, the four pairs shown in Table 21, from which the albino individuals were produced, are to be designated by the following scheme: 


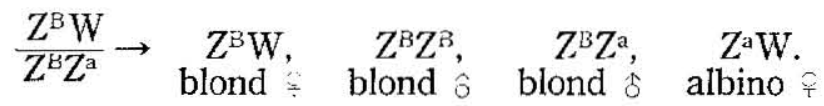

In this scheme, the ratio of the blond birds to the albino ones is $3: 1$, and the latter should all be females. Both sexes of albino individuals, however, were produced from the four pairs in approximately equal numbers, as shown in Table 21 . Thereforc, the albino character seems to be inherited as a Mendelian recessive, with only a singlc factor difference between albino and blond; and neither blond nor albino character shows the sex-linked inheritance in these cases. This is the first reason why the formula $Z^{\mathrm{B}} \mathrm{Z}^{\mathrm{a}}$ for the male parents of the albino birds is not adequate.

(ii) The second reason for this may be seen from the experimental results shown in Table 23. The genetic formula for the white female, either pure or hybrid, is $Z^{\mathrm{b}} \mathrm{W}$ as previously mentioned. The breeding results obtained from the crossing of the white females with the male parents (blond) of the albino birds may be denoted by the following scheme:

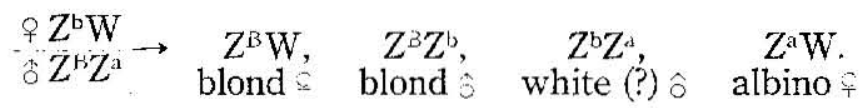

Since the relation between the two factors $b$ and $a$ is not known, the actual character of plumage developed by the combination of these two factors can not be determined. And so it is designated as "white (?)." If we assume that "white (?)" would actually develop into blond in appearance, one fourth of the whole number of individuals in the offspring should be albino birds, and if we assume it to be white or albino, one half of the whole number of individuals produced should be white or albino. There occurred, however, neither white nor albino birds at all in the offspring from these matings. The total number of individuals produced was 39, and they were all blond without exception. The deviation and the standard error of the experiments, calculated on the assumption that the ratio of the blond birds to the albino ones is $3: 1$, are \pm 9.75 and \pm 2.70 , respectively, and those calculated on the assumption that the ratio of the blond birds to the white or albino ones is $1: 1$, are \pm 19.5 and \pm 3.12 , respectively. The deviation exceeds three times the standard error in either case, and so the experimental results are not explainable by the scheme of $\begin{aligned} & Z^{\mathrm{b}} W \\ & \mathrm{Z}^{\mathrm{B}} Z^{\mathrm{a}}\end{aligned}$. 
This is the second evidence that the genetic constitution of the male parents of the albino birds is not to be designated as $Z^{\mathrm{B}} Z^{\mathrm{a}}$.

(3) From the experimental results obtained subsequently from the crossing of albino with white ring doves, producing blond birds in the offspring, as shown in Tables 24 and 25 , we can see that the blond color of plumage in the ring dove is due to two factors, apparently complementary factors. This appearance of blond-colored plumage resembles that found in the offspring of fowls produced from the crossing of two races of the white fowls, $v i z$., the White Dorking and the White Silkie (BATESON and PLNNETT, 1908). But, since the white ring dove is distinguishable phenotypically from the albino ring dove, the former being white in plumage but having very light cream-colored neck-mark and light-grey spotted tail-feathers as well as dark eyes in the adult stage (Plate I, C and D), while the latter being snow-white in plumage and having pink eyes (Plate I, E and F), the writer will suggest that the blond color of plumage in the ring dove is due to two factors, that is, an intensity factor " $I$ " in addition to a color factor " $C$ " which is responsible for developing the plumage color and eye color characteristic of the white ring dove. The white ring dove, therefore, may be regarded as a dilute form of the blond ring dove.

Now if we assume that the $C$-factor is an autosomal factor and that the $I$-factor is a sex-linked factor, and that the blond color of plumage is due to the two factors $C$ and $I$, while the white and the albino characters are due to a single factor $C$ and $I$, respectively, then the genetic formulae for the three kinds of ring doves may be designated as follows:

$$
\begin{aligned}
& \text { Blond ring doves: } \quad==\mathrm{CCZ}^{\prime} \mathrm{W}, \quad \hat{\mathrm{s}}=\mathrm{CCZ}^{\prime} Z^{\prime} \text {; } \\
& \text { White ring doves: }=\mathrm{CCZ}^{\mathrm{W}} \mathrm{W}, \quad \text { s }=\mathrm{CCZZ}^{\mathrm{i}} \text {; } \\
& \text { Albino ring doves: } \hat{\imath}=\mathrm{cc} Z^{\mathrm{I}} \mathrm{W}, \quad \hat{\mathrm{o}}=\mathrm{cc} Z^{\mathrm{I}} \mathrm{Z}^{\mathrm{I}} \text {. }
\end{aligned}
$$

The factor $C$ develops the colors for plumage and eye characteristics in the white ring dove as mentioned above, while the factor $I$ can not exhibit any coloration by itself and causes the bird to remain an albino. It seems probable that the snow-white plumage and reddish eye characteristic of the albino ring dove are displayed as a result of the isolation of the factor $I$.

If the above assumptions are correct, various forms of the 
experimental results presented in the foregoing tables should be explained by these formulae. Thus:

(a) White $\because \times$ Albino $\hat{s}$.

\begin{tabular}{|c|c|c|c|}
\hline $\mathrm{P}_{1}$ & $\begin{array}{l}\mathrm{CCZ}^{\mathrm{i} W} \\
\text { white }\end{array}$ & $x$ & $\begin{array}{c}\operatorname{cc}^{\prime} Z^{1} \\
\text { albino }\end{array}$ \\
\hline$P_{1}$ gametes & $(\mathrm{CW}),\left(\mathrm{CZ}^{\mathrm{i}}\right)$ & & $\left(\mathrm{c} Z^{\mathrm{I}}\right)$ \\
\hline$F_{1}$ & $\begin{array}{c}\mathrm{CcZ}^{\prime} \mathrm{W} \\
\text { blond } \\
1\end{array}$ & & $\begin{array}{l}\mathrm{CcZ}^{\mathrm{I}} \mathrm{Z}^{\mathrm{i}} \\
\text { blond } \hat{\delta} \\
1\end{array}$ \\
\hline
\end{tabular}

(b) Albino $\times$ White $\hat{s}$.

\begin{tabular}{|c|c|c|c|}
\hline$P_{1}$ & $\begin{array}{c}\operatorname{ccZ}^{i} W \\
\text { albino } 2\end{array}$ & $x$ & $\begin{array}{r}\mathrm{CCZ}^{\mathrm{i}} \\
\text { white } \hat{3}\end{array}$ \\
\hline $\mathrm{P}_{1}$ gametes & $(\mathrm{cW}),\left(\mathrm{c} Z^{\mathrm{I}}\right)$ & & $\left(\mathrm{C} Z^{\mathrm{i}}\right)$ \\
\hline $\mathrm{F}_{1}$ & $\begin{array}{c}\mathrm{CcZ}^{\mathrm{W}} \mathrm{W} \\
\text { white } \\
1\end{array}$ & & $\begin{array}{c}\mathrm{CcZ} Z^{i} \\
\text { blond } \hat{3} \\
1\end{array}$ \\
\hline
\end{tabular}

The offspring $\left(\mathrm{F}_{1}\right)$ produced from the mating of White $\times$ Albino $s$ are all blond, whereas that from the reciprocal mating, i.e., Albino $\times$ White , are both blond and white, blond individuals being male and white ones female. The experimental results shown in Tables 24 and 25 are well explained by the scheme mentioned above, the actual numbers secured being not far from the theoretical ones.

(4) The results of the crossing between the blond and the white ring doves are also satisfactorily explained by the same scheme as follows:

\begin{tabular}{|c|c|c|c|c|c|}
\hline $\mathrm{P}_{1}$ & & $\begin{array}{l}\text { Blond } \\
\mathrm{CCZ}^{\mathrm{I} W}\end{array}$ & $x$ & $\begin{array}{c}\text { White ò } \\
\text { CCZZi }\end{array}$ & \\
\hline $\mathrm{P}_{1}$ gametes & & $(\mathrm{CW}),\left(\mathrm{CZ} Z^{\mathrm{I}}\right)$ & & $\left(\mathrm{CZ} \mathrm{Z}^{\mathrm{i}}\right)$ & \\
\hline $\mathrm{F}_{1}$ & & $\begin{array}{l}C C Z \mathrm{~W} \\
\text { white }\end{array}$ & $x$ & $\begin{array}{r}\mathrm{CCZ} Z^{\mathrm{i}} \\
\text { blond }\end{array}$ & \\
\hline $\mathrm{F}_{1}$ gametes & & $(\mathrm{CW}),\left(\mathrm{CZ}^{\mathrm{i}}\right)$ & & $(\mathrm{CZ}),(\mathrm{CZ})$ & \\
\hline $\mathrm{F}_{2}$ & $\begin{array}{l}\mathrm{CCZ}^{1} \mathrm{~W} \\
\text { blond }\end{array}$ & $\begin{array}{l}\mathrm{CCZ} Z^{1} \\
\text { blond }\end{array}$ & & $\begin{array}{l}\mathrm{CCZ}^{\mathrm{i} W} \\
\text { white }\end{array}$ & $\begin{array}{l}\mathrm{CCZZ} \\
\text { white }\end{array}$ \\
\hline & 1 & : $\quad 1$ & : & $1:$ & 1 \\
\hline
\end{tabular}


(b) White o $\times$ Blond $\hat{\circ}$

\begin{tabular}{|c|c|c|c|c|c|}
\hline$P_{1}$ & & $\begin{array}{l}\text { White } \\
\text { CCZW }\end{array}$ & $x$ & $\begin{array}{r}\text { Blond } 8 \\
\text { CCZI' }\end{array}$ & \\
\hline $\mathrm{P}_{1}$ gametes & & $(\mathrm{CW}),(\mathrm{CZ})$ & & $\left(\mathrm{CZ} Z^{\mathrm{i}}\right)$ & \\
\hline$F_{1}$ & & $\begin{array}{l}\mathrm{CCZ}^{\mathrm{I}} \mathrm{W} \\
\text { blond }\end{array}$ & > & $\begin{array}{l}\mathrm{CC} Z^{\mathrm{i}} \mathrm{i}^{\mathrm{i}} \\
\text { blond }\end{array}$ & \\
\hline$F_{1}$ gametes & & $(\mathrm{CW}),(\mathrm{CZ})$ & & $\left(\mathrm{CZ}^{\mathrm{I}}\right),(\mathrm{CZ}$ & \\
\hline $\mathrm{F}_{2}$ & $\begin{array}{l}\mathrm{CCZ}^{\mathrm{T}} \mathrm{W} \\
\text { blond }\end{array}$ & $\begin{array}{r}\mathrm{CCZ}^{\mathrm{I}} \mathrm{Z}^{\mathrm{I}} \\
\text { blond } 6\end{array}$ & & $\begin{array}{l}\mathrm{CCZ}^{\mathrm{I} Z^{\mathrm{i}}} \\
\text { blond }\end{array}$ & $\begin{array}{l}\mathrm{CCZ}^{\mathrm{C}} \mathrm{W} \\
\text { white }\end{array}$ \\
\hline & 1 & ${ }^{\circ}$ & & $:$ & 1 \\
\hline
\end{tabular}

The blond ring dove is denoted by $\mathrm{CCZ}^{1} \mathrm{~W}$ and $\mathrm{CCZ}^{1} Z^{1}$ instead of $Z^{\mathrm{B} W}$ and $Z^{\mathrm{B}} Z^{\mathrm{B}}$, and the white ring dove by $\mathrm{CCZ}^{\mathrm{i}} \mathrm{W}$ and $\mathrm{CCZ}^{\mathrm{i}} \mathrm{Z}^{\mathrm{i}}$ instead of $Z^{\mathrm{b}} \mathrm{W}$ and $Z^{\mathrm{b}} Z^{\mathrm{b}}$. Since the factor $C$ is common to the two races, the factors $I$ and $i$ act upon it as $B$ and $b$ do, when these two are crossed with each other.

(5) The various cases of crossing among the albino birds and their related ones are well explained by the same scheme, too. Thus :

(a) The crossing of the albino individual with its male parent. (Table 20). ${ }^{1}$

If we assume the genetic formula for the male parents of albino individuals as $\mathrm{CcZ} Z \mathrm{Z}$, that is, heterozygous with respect to the factor $C$, the case will be well explained as follows:

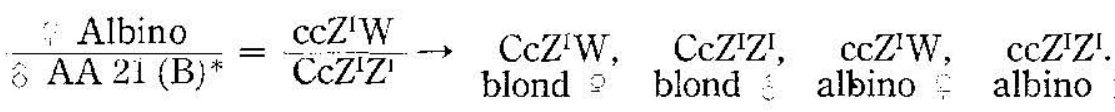

(b) The crossing of the white female with the male parent of the albino individual. (Table 23). ${ }^{1}$

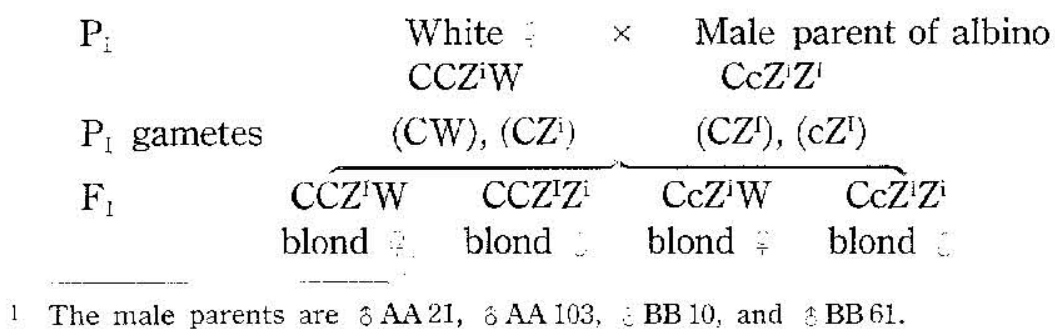


The occurrence of the white or albino offspring is not expected by this scheme, whereas it is expected by the $Z^{\mathrm{b}} \mathrm{Z}^{\mathrm{a}}$-scheme.

(c) The crossing of the female parent of the albino individual with the white male or the hybrid blond male. (Table 19). ${ }^{1}$

The female parents were designated as $Z^{\mathrm{B}} \mathrm{W}$ (p. 184). Now what is the formula for the female parents when we apply the two factors $C$ and $I$ ? As will be seen later, it should be $C \mathrm{cZ}$ W (p. 190).

(i) Female parent of albino $\times$ Hybrid blond $\mathrm{s}$.

$\mathrm{P}_{1}$

Female parent $\times$ Hybrid blond ; $\mathrm{CcZ}{ }^{\mathrm{I} W}$

$\mathrm{CCZ} Z \mathrm{Z}$

$\mathrm{P}_{1}$ gametes $(\mathrm{CW}),(\mathrm{cW}),(\mathrm{CZ}),(\mathrm{cZ}) \quad\left(\mathrm{CZ}^{\mathrm{I}}\right),\left(\mathrm{CZ}^{\mathrm{i}}\right)$

$\mathrm{F}_{1} \mathrm{CCZ}^{\mathrm{I} W}, \mathrm{CcZ}^{\mathrm{I} W}, \mathrm{CCZ}^{\mathrm{I} Z^{1}}, \mathrm{CcZ}^{\mathrm{I} Z} \mathrm{C}^{\mathrm{I}}, \mathrm{CCZ}^{\mathrm{I} Z}, \mathrm{CcZ}^{\mathrm{I} Z^{i}}, \underbrace{\mathrm{CCZ} W}, \mathrm{CcZ}^{\mathrm{i} W}$ : white 9 's

Blond $?=2$, blond $=4$, and white $?=2$, a ratio of $1: 2: 1$.

(ii) Female parent of albino $\times$ White 8 .

\begin{tabular}{|c|c|c|}
\hline$P_{1}$ gametes & $\begin{array}{r}\text { Female parent } \\
\mathrm{CcZ}^{I} \mathrm{~W} \\
(\mathrm{CW}),(\mathrm{cW}),(\mathrm{CZ}),(\mathrm{cZ})\end{array}$ & $\begin{array}{l}\times \quad \begin{array}{l}\text { White } \\
\text { CCZZZi }\end{array} \\
\text { (CZi) }\end{array}$ \\
\hline$F_{i}$ & $\overline{\mathrm{C} C Z^{i} Z^{i}, \mathrm{CcZ}^{i} Z^{\mathrm{i}}}$ & $\mathrm{CCZ}^{\mathrm{i} W}, \mathrm{CcZ} W$ \\
\hline & $\begin{array}{c}\text { blond } \\
1\end{array}$ & $\begin{array}{c}\text { white } \\
1\end{array}$ \\
\hline
\end{tabular}

(d) The interpretation of the occurrence of the albino individuals in the offspring of the four pairs, by the two-factor formula.

The formula for the male parents of the albino individuals is designated as $\mathrm{CcZ}^{\mathrm{Z}} \mathrm{Z}^{\mathrm{I}}$, as already mentioned. The formula for the female parents may be denoted as $C c Z^{\prime} W$, heterozygous with respect to the factor $C$ like that of the male parents. The results of breeding are expected as follows:

1 The female parents are $=\mathrm{BB} 8, \mathrm{BB} 118, \mathrm{AA} 110$, and AA112. 


$$
\begin{aligned}
& \mathrm{P}_{1} \quad \text { Female parent } \times \text { Male parent } \\
& \mathrm{CcZ}^{\mathrm{I} W} \quad \mathrm{CcZ} Z^{\mathrm{I}} \\
& \mathrm{P}_{1} \text { gametes }(\mathrm{CW}),(\mathrm{cW}),\left(\mathrm{CZ}^{\mathrm{I}}\right),\left(\mathrm{c} Z^{\mathrm{I}}\right) \quad\left(\mathrm{CZ}^{\mathrm{I}}\right),(\mathrm{cZ})
\end{aligned}
$$

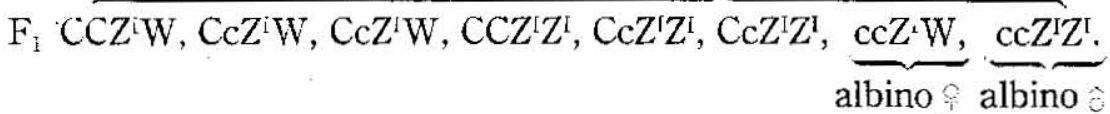

The ratio of the blond individuals to the albino ones is $6: 2$ or $3: 1$, and both sexes of albino individuals are to be produced in equal numbers. The experimental results presented in Table 21 are in agreement with the theoretical expectation mentioned above. If, on the other hand, we assume the genetic constitution of the female parents to be $\mathrm{CCZ}^{\mathrm{I}} \mathrm{W}$, i.e., homozygous with respect to the factor $C$, no albino individual will be expected to occur.

(6) The albino individuals breed true. An albino female was mated to an albino male, both being the progeny of the pair No. 32 (Table 21), and they have bred 19 individuals up to the present, all albino, 9 being females and 10 being males, as shown in Table 22. It is seen, from the experimental results shown in Tables 20, 21, and 22, that the two characters, blond and albino, form an allelomorphic pair, albino being a simple Mendelian recessive to blond. Consequently, the albino individuals which occurred in the offspring of the four pairs are homozygous with respect to the characters under consideration. The homozygosis of the albino character may also be confirmed by the formula derived from the two-factor hypothesis, as mentioned above.

(7) An Inquiry into the Cause of the Occurrence of Albino Individuals. As has been shown, the parents of the albino individuals were heterozygous with respect to the factor $C$, the male being $\mathrm{CcZ}^{\mathrm{I}} \mathrm{Z}^{\mathrm{I}}$ and the female $\mathrm{Cc} \mathrm{Z}^{\mathrm{W}} \mathrm{W}$, and the nccurrence of albino individuals is considered to be due to this heterozygosis of the parents, and so we must trace the origin of the factor $c$, an allelomorph of $C$. There is good evidence to believe that the male birds AA 109 and AA 111 (Cf. TAXGE, 1932, figs. 1 and 2, p. 2.) which were the male parents of $\mathrm{BB} 10, \mathrm{BB} 61$, and $\mathrm{BB} 118$, were not heterozygous with respect to the factor $C$, because these two males had been mated with $2 \mathrm{AA} 110$ and $\mathrm{AA} \mathrm{112}$, respectively, which were heterozygous, as has been previously mentioned. They produced, however, no albino individuals in their offspring, 
and consequently two pairs of the original stock, No. $14=\frac{\mathrm{AA} 18}{\mathrm{AA} 14}$ and No. $7=\frac{\mathrm{AA} 11}{\mathrm{AA} 16}$, parents of $\mathrm{AA} 109$ and AA 111 , respectively, have no connection with the occurrence of the albino individuals. The other two pairs of the original stock, viz., No. 12 $=\frac{\circ \mathrm{AA}}{3 \mathrm{AA}} 17$ and No. $13=\frac{\mathrm{AA} 15}{\mathrm{AA} 12}$ are related to the occurrence of albino individuals; and one of the two birds $\mathrm{AA} 5$ and AA 17 as well as one of the two birds AA 15 and AA 12 are considered to have had the factor $c$. These four birds were purchased from a bird-fancier and no further pedigree is traceable beyond them.

Now inquiring into the origin of the factor $c$, we may consider two causes: mutation and segregation.

As early as 1813, Temminck described the White Dove, and it resembles the writer's albino ring dove, except in the morphological account of it, viz., its small size and the different proportions of its wings and tail. TEMMINCK's description follows in translation:

"The White Dove is smaller than the Blond Dove; it is about an inch less in total length, and its tail is shorter. Its wings, longer in proportion, reach back three-fourths of the length of the tail, while the wings of the Blond Dove erd at about the middle of the tail, which in this species is lengthened and more tapered. Finally, the White Dove has a milk white plumage throughout, the feet are rosered, the iris is red, and the bill is dusky red." (Wumtsis: and Ritil:, 1919, P. 195:

TeMminck regarded the White Dove as a species distinct from the Blond Dove. WhrTMan, on the other hand, regarded the white ring dove as a species distinct from the blond ring dove; and the white ring dove described by WHITMAN is the same as that of the writer, according to the writer's personal observations during his stay at Dr. RIDDLE's laboratory in 1925 . It seems to the writer that WHITMAN did not recognize the existence of TEMmiNCK's White Dove.

The writer has been unable to find albino ring doves anywhere else in his country even though he made great efforts to do so after the occurrence of these birds in his aviary, and he considers the cause of the occurrence of the albino individuals as a gene mutation which probably took place in his strain of birds at some time before they came under his care. The mutated gene is denoted by "c." 
It is to be expected, as a matter of course, that two kinds of homozygous albino ring doves will occur, they are to be different to each other genotypically, viz., the one being $c c Z^{I} \mathrm{~W}$ and $c c Z^{I} Z^{\mathrm{I}}$ and the other $c c Z^{i} W$ and $c c Z Z Z$. These breeding experiments are now in progress. And the writer wili distinguish them, if necessary, by calling the former "Albino I" and the latter "Albino II."

(8) The Intensity Factor in Domestic Pigeons. Cole (1912) and his students (Cole and Kelley, 1919; Steele, 1931; Hawkins, 1931) studied about the intensity factor in domestic pigeons, Columba livia, finding it to be sex-linked and necessary for the full development of the intensity of red and black colors of plumage. In the absence of this factor colors remained in dilute condition, red appearing yellow and black as dun. The intensity factor $I$ in ring doves is somewhat similar to that in domestic gigeons, but in the former, in the absence of this factor, the black color in the neck-mark and in the tail feathers remains in a very dilute condition exhibiting very light cream color or light grey, and the blond color of plumage becomes white. It is apparently more intense in this case than in the case of pigeons. Whether the one is identical with the other or not might be revealed by raising the interspecific crosses from the mating of the pigeon with the ring dove, if the crosses produced be sterile males only (WHITMAN and RidDi.e, 1919).

\section{SUMMARY}

(1). The blond color of plumage in the ring dove is sex-linked in inheritance when the blond ring dove is crossed with the white ring dove, the male being homogametic and the female hetero. gametic.

(2). The blond color of plumage in the ring dove is inherited as an autosomal character when the blond ring dove is crossed with the albino ring dove ("Albino I"), blond being a simple Mendelian dominant over albino.

(3). Ring doves of blond color in plumage appear in the offspring produced from the crossing of the albino ring dove ("Albino I") with the white ring dove.

(4). The blond color of plumage in the ring dove is developed by the combination of two factors, the one being that which is 
responsible for the white splumage color and the dark eye color characteristic of the white ring dove, and the other being the intensity factor. The intensity factor can not develop any coloration by itself. It leaves the bird an albino, the plumage being snow-white and the eye red.

(5). The factor for the characteristic white plumage color and eye color of the white ring dove is denoted by $C$ and the intensity factor by $I$.

(6). The factor $C$ is autosomal and the factor $I$ is sex-linked.

(7). The albino ring dove which has the $I$-factor but is lacking in the $C$-factor, named "Albina I," is considered to have occurred in consequence of the gene mutation, the $c$ having mutated to $C$. This new kind of ring dove breeds true and has established a new race.

(8). Another kind of albino ring dove is expected to be bred, which is lacking in both $C$ and $I$ and will be named "Albino II," viz., $\mathrm{ccZ}^{\mathrm{i} W}$ and $\mathrm{ccZ} \mathrm{ZZ}^{\mathrm{i}}$.

In conclusion, acknowledgment is due to Prof. Y. TANAKA, Prof. Y. TAKEZAKI, and Prof. M. So, to whom the writer is indebted for valuable suggestions in accomplishing this work.

Laboratory of Zootechny, Department of Agriculture,

Kyushu Imperial University, August, 1934.

\section{BIBLIOGRAPHY}

1. Batess, W. 1913. Mendel's principles of heredity. Pp. 101-106.

2. Bunnt, J. 1923. Tranformation expérimentale du sexe par ovariotomie précoce chez la Poule domestique. C. R. Acad. Sci., 177. P. 1074.

3. Cifistir, W. und C. WRIidT. 1927. Schokolade, ein neuer geschlechtsgebundener Farbencharakter bei Tauben. Zeitschr. indukt. Abstamm.- u. Vererbungslehre, 43. Ss. 391-392.

4. Cor E, L. J. 1912. A case of sex-linked inheritance in the domestic pigeon. Science, 36. Pp. 190-192.

5. Cor., L. J. 1914. Studies on inheritance in pigeons. I. Hereditary relation of the principal colors. Rhode Island Agric. Expt. Sta. Bull. 158. Pp. 311-380.

6. Col, L. J. and F. J. K.LLF. 1919. Studies on inheritance in pigeons. III. Description and linkage relation of two sex-linked characters. Genetics, 4. Pp. 183203.

7. CRrw, F. A. E. 1923. Studies in intersexuality. II. Sex-reversal in the fow1. Proc. Roy. Soc. B., 95. Pp. 25€-278.

8. Dom, L. V. 1929. Spermatogenesis following early ovariotomy in the brown Leghorn fowl. Proc. Soc. Exp. Biol. and Med., 26. Pp. 338-341. 
9. H.wk:Ns, L. E. 1931. Studies on inheritance in pigeons. X. Relation of chocclate to black and dominant red. Genetics, 16. Pp. 547-573.

10. Moron, T. H. 1919. The physical basis of heredity. Pp. 177-183.

11. Occmi, K. 1927. Studies on the sauropsid chromosomes. I. The sexual difference of chromosomes in the pigeons. Jour. Coll. Agric. Hokkaido Imp. Univ., 16. Pp. 203.227.

12. Ruxr, O. 1924. A case of complete sex-reversal in the adult pigeon. Amer. Nat., 58. Pp. 167-181.

13. RidDt, E, O. and E. H. B Grer. 1921. Stuclies on the physiology of reproduction in birds. IX. On the relation of stale sperm to fertility and sex in ring doves. Amer. Jour. Physiol., 57. Pp. 228-249.

11. Sarvaupz, T. 1893. Catalogue of the Columbae, or pigeons in the collection of the British Museum.

15. Sraptas-BR,wNE, R. 1912. Second report on the inheritance of color in pigeons, togetner with an account of some experiments on the crossing of certain races of doves, with special references to sex-limited inheritance. Jour. Genetics, 2. Pp. 131-162.

16. Str:t., D. G. 1931. Studies on inheritance in pigeons. IX. The chocolate-brown plumage color. Genetics, 16. Pp. 532-546.

17. StriNG, R. M. 1912. Results of hybridizing ring doves, including sex-linked inheritance. Biol. Bull., 23. Pp. 293-320.

18. TANAKA, Y. 1924. A new sex-linked mutation in the silkworm, Bombyx mori L. Jour. Dept. Agric., Kyushu Imp. Univ., I. Pp. 135-150.

19. Tanor, M. 1932. Unexpected occurrence of albino individuals in the offspring of blond ring doves, Streptopelia risoria. (In Japanese with an English résumé). Jap. Jour. Genetics, 8. Pp. 1-18.

20. Trmmines, C. J. 1813. Histoirc naturelle générale des pigeons, Vol. I. Pp. 223-335..

21. Wilitmax, C. O. 1919. Inheritance, fertility, and the dominance of sex and color in hybrids of wild species of pigeons. Vol. 2, edited by O. Rip»rs. Carnegie Instit. Publ., No. 257. Pp. 123-147 and 189-200.

22. Zaw.s:ywsк', M.. 1926. Bisexual nature of the hen and experimental hermaphroditism in hens. Trans. Lab. Exp, Biol.. Zoopark Moscow, 2. Pp. 164-179.

\section{EXPLANATION OF PLATE I}

A. Adult female blond ring dove. $\times 0.3$. S. Nosmos del., Oct. 1933.

B. Outer (right) tail feather of the blond ring dove, under side. $\times 0.3$.

C. Adult female white ring dove. $\times 0.3$. S. Nisurna del., Oct. 1933.

D. Outer (right) tail feather of the white ring dove, under side. $\times 0.3$.

E. Adult female albino ring dove. $\times 0.3$. S. Nishir. del., Oct. 1933.

F. Outer (right) tail feather of the albino ring dove, urder side. $\times 0.3$. 
Jour. Dept. Agric, Kyush Imp, Unix. Vol 4

Plate I

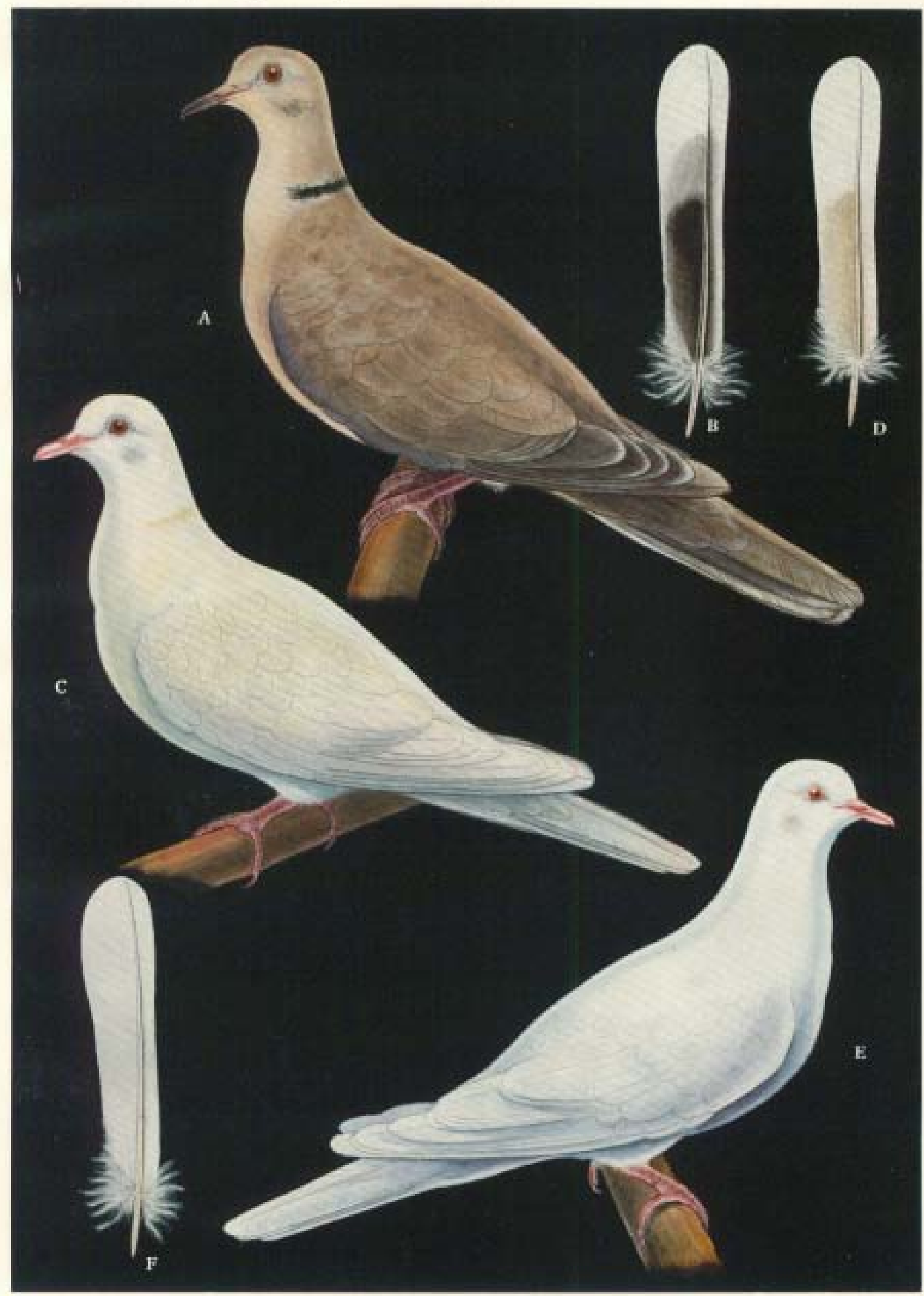

